\title{
RED DEER ANTLER AS RAW MATERIAL AT THE NEOLITHIC SITE OF SAMOVODENE, VELIKO TARNOVO DISTRICT (CENTRAL NORTHERN BULGARIA)
}

\author{
Hristina Markova \\ Historical Museum of Nova Zagora, Bulgaria \\ e-mail: hdmarkovi@gmail.com | Original scientific paper \\ Received: 21. 4. 2020. UDC: 903.01-035.56"634" \\ Accepted: 23. 6. 2020. 903.2-035.56"634" 902.2(497.2)"1974/..."
}

\begin{abstract}
The Neolithic site of Samovodene (Veliko Tarnovo district) is situated in the north-eastern part of the village on a high non-flooding plain on the left bank of the Yantra River. Archaeological excavations were carried out by Peter Stanev (in 1974, because of road construction activities) and Nedko Elenski (between 1999 and 2000, because of renovation works on the Veliko Tarnovo-Ruse highway). There are five cultural layers and eleven construction horizons distinguished, with no visible hiatus among them, which makes the settlement one of the most important Neolithic sites in the Lower Danube basin. The archaeozoological analyses provided information about a very large percent of red deer (Cervus elaphus) bones at Samovodene, placing it second in animal exploitation, after cattle (Bos taurus). Over 350 artefacts made of bones were found during the archaeological excavations. Eighty pieces of them were made of red deer antlers, classified in six groups: sickles, punching tools, bevelled tools, handles and undetermined objects. There is a constant distribution of the findings by layers on Samovodene, with the exception of layer B2-C, where only two finds were registered. The production of red deer antler tools is very specialized in terms of both technology and typology and we can see that this raw material was concentrated around two major types of tools related to the agriculture and lithic industry. The fairly well-standardized technology and the simple set of tools indicate a good knowledge of red deer antler properties and qualities and their adaptation to the needs of the Neolithic way of life. It seems that the inhabitants had known this material very well since the inception of the settlement, which proves that knowledge on antler industry had been learned elsewhere and had been passed on to Samovodene through generations.
\end{abstract}

Keywords: red deer antler tools; antler technology; antler tool typology; Early Neolithic; Central Northern Bulgaria

\section{Introduction}

Worked bones are often found during archaeological excavations. One of the important bone materials are red deer antlers, which are strong enough and have a higher degree of elasticity than bones in adapting to prehistoric set of items. This paper presents objects made of antler from the Neolithic tell in 


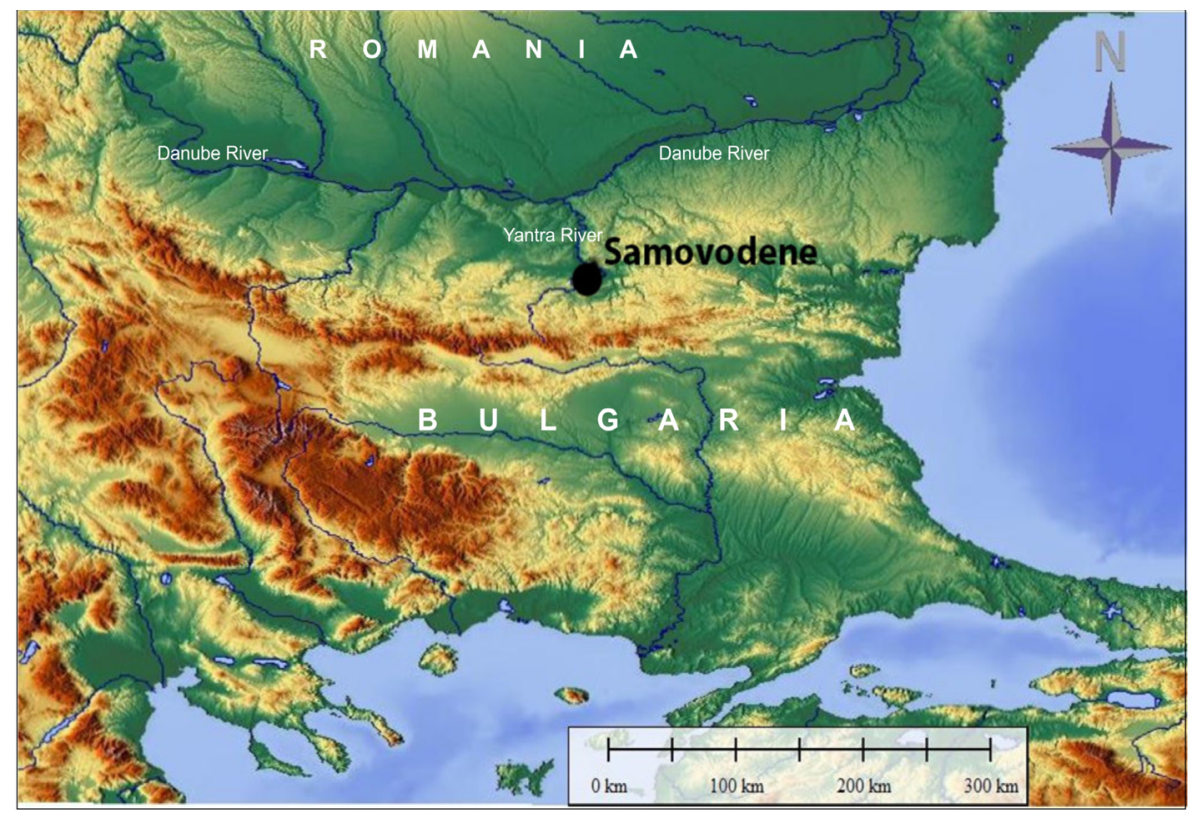

Fig. 1. Location of the site of Samovodene

Сл. 1. Положај локалитета Самоводене

the village of Samovodene (Central Northern Bulgaria). The village is situated about $10 \mathrm{~km}$ to the north from the city of Veliko Tarnovo (Fig. 1). Archaeological excavations began under the direction of Peter Stanev in 1974 because of road construction activities. The excavations were conducted in 9 sectors (Fig. 2). The maximum thickness of the cultural layers reached up to $4.50 \mathrm{~m}$ in the central part of the tell. The research of the north-eastern part at the central sector V was key in the stratification of the site. There are five cultural layers and eleven building horizons with no hiatus among them (Станев 1982, 3; Станев 1997, 39; Станев 2002, 42-43). On the basis of ceramic material, Peter Stanev distinguished five phases of development of the settlement. During the archaeological excavations, several samples from animal bones were taken, which correspond to the absolute dates presented here:

Layer A - 5626-5513 cal BC

Layer B1 - 5970-5747 cal BC

Layer B1/B2 - 5484-5375 cal BC

Layer B - 5558-5472 cal BC cal BC (Marinova, Krauß 2014, Table 2, p. 190).

After these large-scale researches, Nedko Elenski carried out rescue field excavations of the site in 1999 and 2000, because of renovation works on the Veliko Tarnovo - Ruse highway. During these excavations, the surface of $70 \mathrm{~m}^{2}$ was 


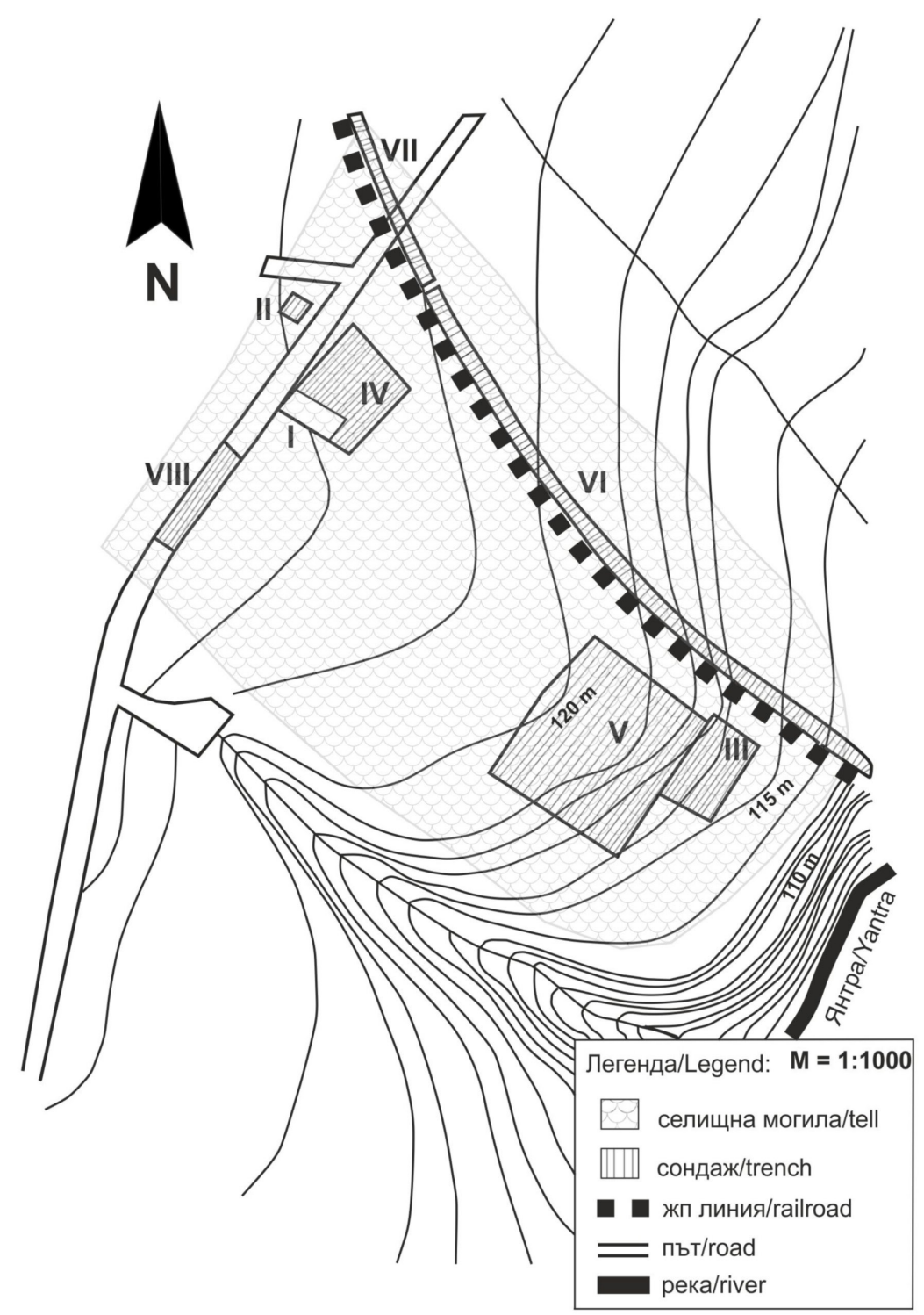

Fig. 2. Plan of the Neolithic site of Samovodene and excavated trenches (after Станев 2002, 242, Обр. 25)

Сл. 2. План неолитског локалитета Самоводене и истражене сонде (према Станев 2002, 242, обр. 25) 
examined. The fact that the stratigraphic profile of the settlement was exposed, in the length of $420 \mathrm{~m}$, is of particular importance. Three layers were distinguished: Samovodene A-B1; Samovodene B1 and B2 and Samovodene B2-C. The maximum size of the settlement varies from 140 to 200 decares over various periods of time (Еленски 2001, 19-20).

It should be noted that there are different opinions in scientific works regarding the periodization of the phases of Samovodene, which are based on the synchronization of the ceramic material with that from tell Karanovo (Southern Bulgaria) (Николов 1998; Станев 1997; Станев 2002). In this paper, we used the periodization of Peter Stanev, which has been in use since 1997: Samovodene A1; A2 - Karanovo II; Samovodene A2-B1 - Karanovo II-II; Samovodene B1; B2 - Karanovo III; Samovodene B2-C - Karanovo III-IV (Станев 1997).

Samovodene is linked to the Early Neolithic culture Ovcharovo, which represents the third and fourth phase of the Early Neolithic in North-eastern and Central Northern Bulgaria. This culture is associated with the reneolithisation of Northern Bulgaria (Тодорова, Вайсов 1993, 77, 132). There is only one publication about a very small part of the processed bone collection from OvcharovoGorata by Peter Zidarov (Zidarov 2014) that we can use for comparison with the Samovodene antler items.

A zooarchaeological analysis of Samovodene was performed by Lazar Ninov (Нинов, Станев 1992). The fauna is represented by 22 species. Domestic animals were more common than the wild: 17 mammal species (99.90\%), 2 bird species and one species of mollusc, one of reptiles and one of fish. The inhabitants were well-versed in livestock breeding, which met the nutritional needs of the population, but wildlife hunting was also practiced, to provide food diversity, but also for the hides. By the number of bones and the minimal number of individual animals, it was observed that the bovine occupied the first place, small ruminants, such as sheep and goats, took the second place, and lastly there were pigs. It was only in the later phase Samovodene B2-C that pigs surpassed small ruminants. When it comes to game - red deer was the main hunting prey during all stages of development of the village and took about $60-70 \%$, as assessed by the minimal number of individual animals among all wild animals (Станев, Нинов 1992, 117-126; 267, Обр. 63).

A total of 361 bone artefacts was found during the archaeological excavations and a small number of them (27) was published in the book of Peter Stanev (Станев 2002). There are 76 artefacts made of red deer antler, classified in six groups: sickles, punching tools, bevelled tools, sockets, undetermined artefacts and debris. 


\section{Red deer antlers}

Antlers are dense skeletal outgrowths, typical for male Cervidae, except for reindeer (Rangifer tarandus), where they are also found in females (Гуадели 2011, 30; Vitezović 2014, 151; Vitezović 2018, 42). Antlers have a similar structure to bones. They consist of compact tissue that is comprised of a calcified crust surrounding the spongy tissue, and the proportions between the two vary depending on the taxa and the antler portion. There is a "transition zone" between the two parts (Billamboz 1977, 99; Crigel et al. 2001, 27). The simplest antlers are those of the roe deer (Capreolus capreolus), which have relatively slender spikes and grow almost vertically from the skull. The most complex and large antlers are those of the red deer (Cervus elaphus), which can reach 0.90-1.20 m in length. Red deer antlers consist of a base, beam, crown and tines (Billamboz 1977, 9697; Vitezović 2014, 152-153; Vitezović 2016, 43). The tines are curved and the crown is well developed. The cross-section is oval, with almost the entire surface covered with irregularities that give the antlers the look similar to tree bark, with the exception of the crown, which is smoother (Vitezović 2014, 153; Vitezović 2018, 43). As a raw material, antlers are available depending on the annual cycle of animal development. Red deer shed their antlers in late winter - between February and April (Schibler 2013, 343; Петков 1999, 61). That means that supplies can be obtained by hunting and gathering.

During the Neolithic, people mainly used antlers of adult deer (3-4 years old), which are sufficiently developed and have at least 5-6 branches (Schibler 2013, 343). There are two methods of getting supplies: hunting and gathering. The latter may not have been an intentional activity, but rather something done in the meanwhile, during assembling expeditions to obtain a variety of natural resources, or they could have been obtained even accidentally, during hunting. The gathering seems to have been rather a secondary method of obtaining antler supplies, while hunting had already been a specialized activity that aimed to supply not only meat but also leather, bone material, veins, trophies. After an animal had been killed, its antlers would have been detached with a stone tool with a cutting edge (Семёнов 1957, 180). The distinction between both methods of supply is complicated to perceive because of the many transformations that a bone would undergo in order to become a finished product. The only certain evidence of antler gathering is the presence of a base, and vice versa - the lack of it could be an indicator of hunting, because the cadavers would have been cut to pieces immediately after the killing in order to enable easier transportation to the village. There are no red deer antler bases in the Samovodene collection. The worked bone assemblage consists mainly of tines with traces of excision at the proximal ends. 
The Neolithic inhabitants of Samovodene preferred tine tips, which is unsurprising because the use of their natural shape and sharpened tips is perfectly suited for making sickles, punching tools or sockets. Even in the case of bevelled tools, the tops hadn't been cut out, but rather transformed by one- or two-way sharpening. Red deer antler tips are very hard and stable, because they are composed of compact tissue covering the spongy tissue. Few artefacts were made from the proximal part of the branches and beam fragments, e.g. some sickles that have been separated from the contact area between the beam and some of the tines.

\section{Sickles}

A total number of 18 sickles was recovered from Samovodene, which have a high degree of fragmentation (Fig. 3). Two variations are defined according to the morphology of objects: curved and L-shaped sickles. The first were made of tines and are therefore arc-shaped. Only two objects fall into the group of L-shaped sickles (Fig. 3: 009; Fig. 4: 051) that were made from the contact zone between the stem and a branch. The proximal part was located at $90^{\circ}$ in relation to the medial part. The débitage of all the sickles was carried out by transversal cutting with a stone or a flint tool, the traces of which can be seen clearly on some of the items (№ 037; 072) in the form of wide facets accompanied by shallow longitudinal and parallel striations (Fig. 4). The technology for shaping the grooves where flints would have been placed was the same. It was longitudinally cut with a chipped stone tool on the inner part of the curve of the antler segment. Traces of cutting, situated on the walls and at both ends, can be observed on most of the sickles (Fig. 4: 030; 051; 060). The finishing consisted of surface smoothing or adding an aesthetical trait with which the basic form of the object didn't change. The smoothing was most likely carried out by grinding on abrasive stones or scraping with chipped stone tools for roughly removing the natural pearly part on the burr. The proximal parts (the handles) were also smoothed, for a more comfortable grip, by scraping. There is a fragmented sickle in the collection with a double-sided perforation made by hand drilling with a flint. Sometimes, the distal edges were embedded or had plastic ornaments added by grinding with an abrasive stone or by string rubbing.

These items are known in archaeological literature as part of the "Neolithic package" and are distinctive Neolithic agricultural elements. The Samovodene collection has similarities to sickles found at other Balkans-Anatolian Neolithic sites (Beldiman, Sztancs 2010, 65, Fig. 7: 3-5; Höglinger 1997, 157-196; 197; Mellaart 1970, CXX: a, b, c, d; Russell 2006, 349; Sidéra 1998, 219, Фиг. 2; 225; Георгиев 1958, 372; Георгиев 1960, 317-318; Гюрова 2008, 54, обр. 2; Ланг 


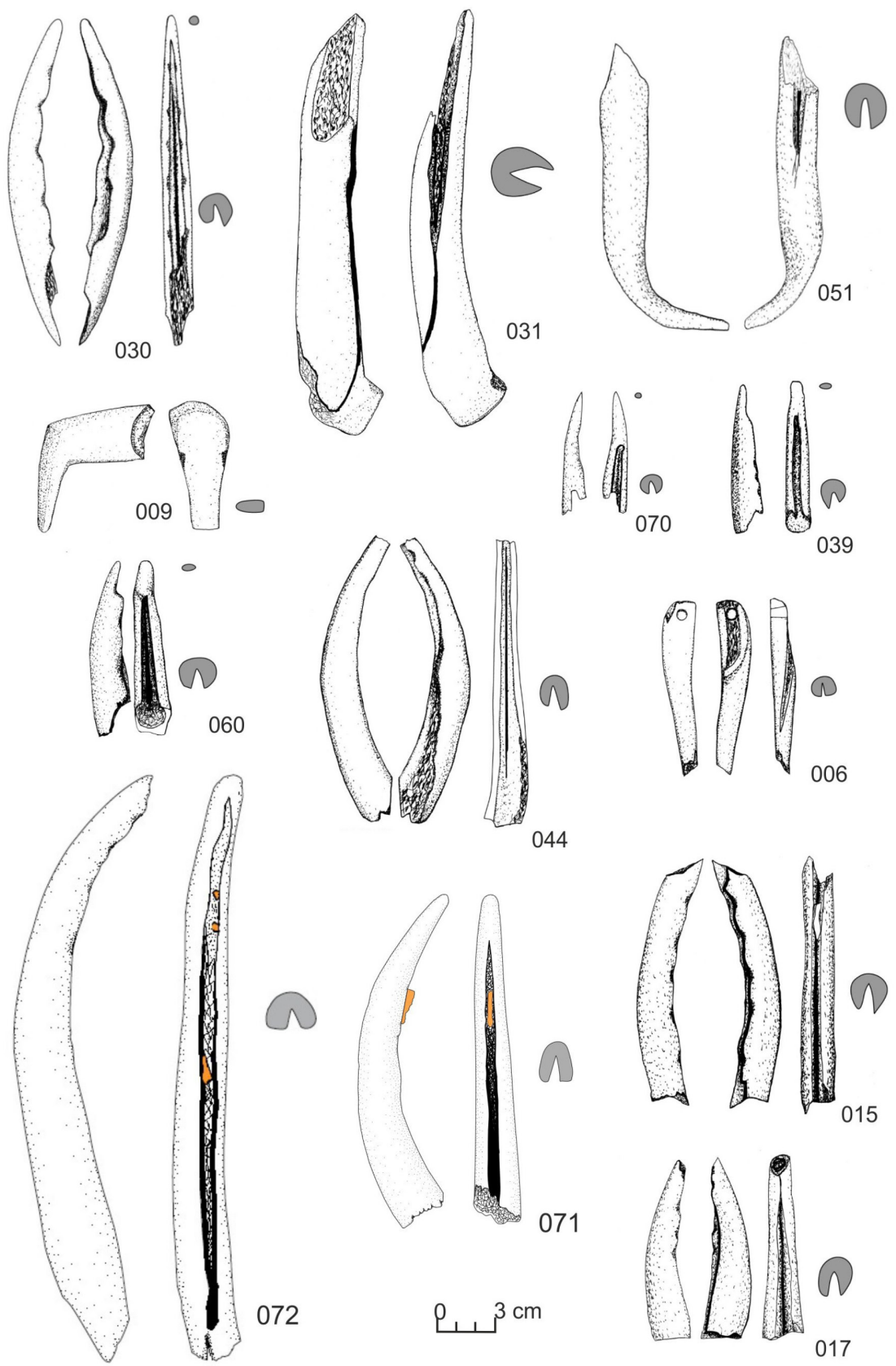

Fig. 3. A selection of red antler sickles from Samovodene Сл. 3. Одабрани српови од рога јелена са Самоводена 

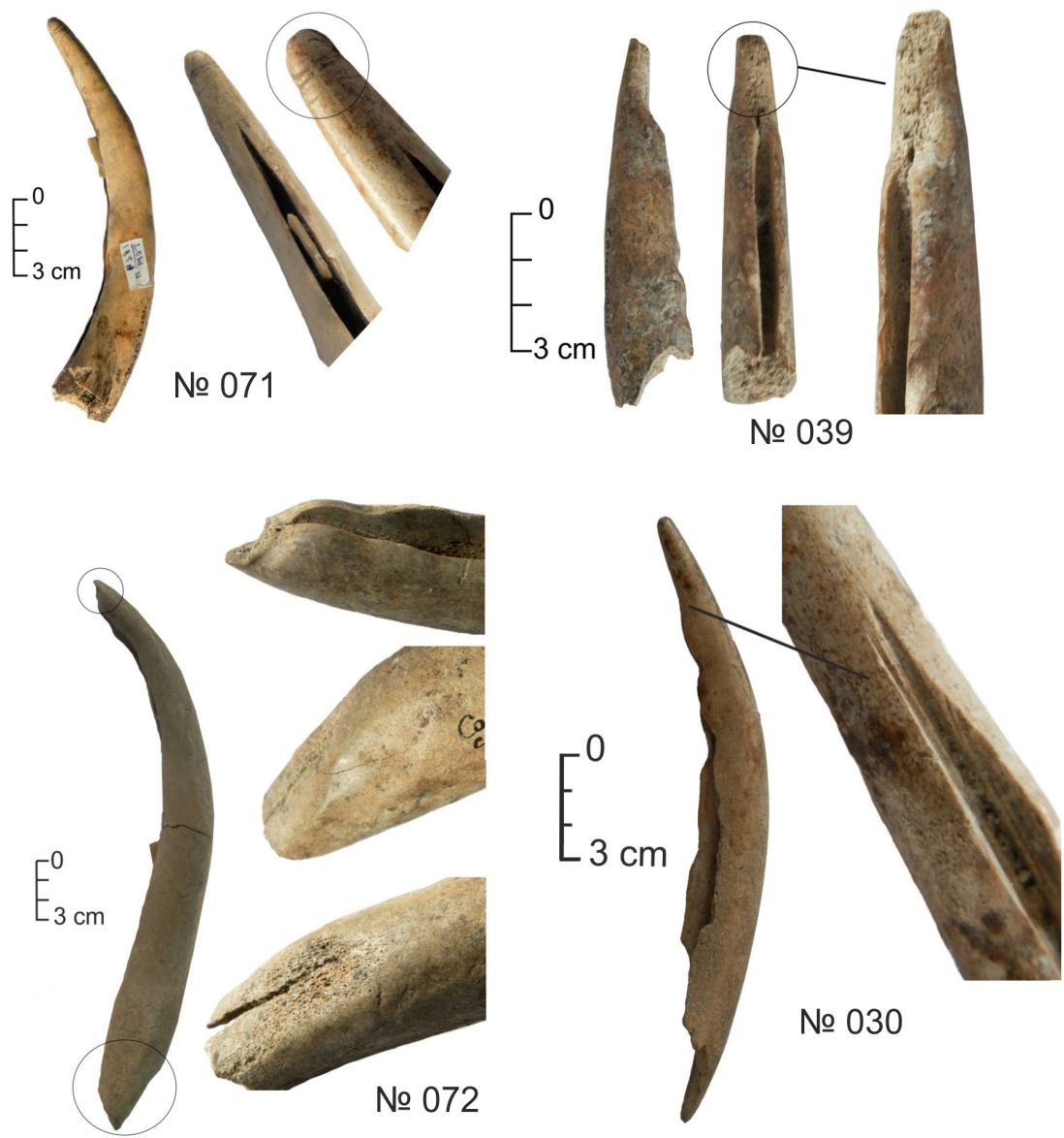

№ 030
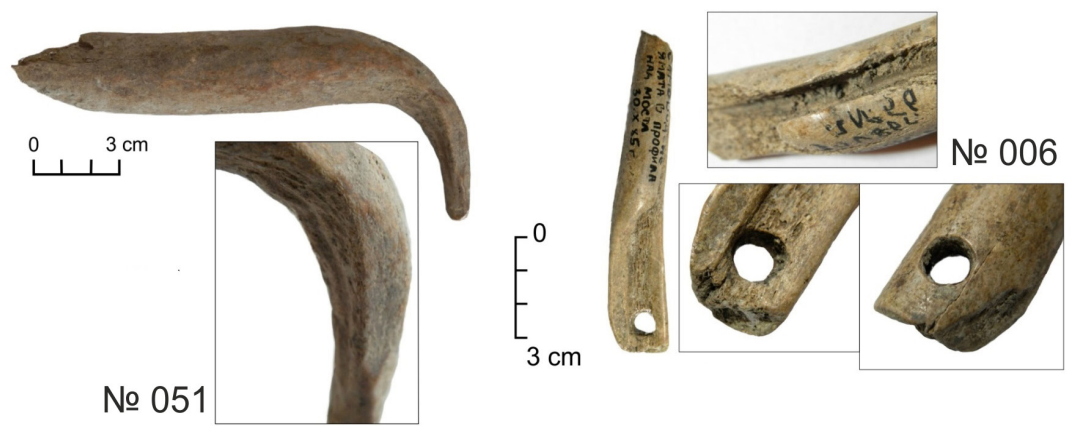

Fig. 4. Details of red deer antler sickles from Samovodene

Сл. 4. Детаљи српова од рога јелена са Самоводена 
2004, 360). The L-shaped variation was also found in the Karanovo II layer at the settlement mound in Karanovo (Höglinger 1997, Tafel 81:1) and OvcharovoGorata (Zidarov 2014, 261, Abb. 191:5). There is a variation named "Karanovo sickles", known from a number of Early Neolithic sites on the territory of Bulgaria, such as tell Karanovo (Георгиев 1958, 371, обр. 2; Gurova 2016, 160161, Fig. 1-4), tell Azmak, Stara Zagora-Okrazhna Bolnitsa, Ovcharovo-Gorata (Zidarov 2014, 259-260), Gradishte (Маркова 2020, 29-30, 36: Фиг. 8), etc. The Karanovo sickles type is characterized by an arc-shaped antler or a wood handle in which chipped stone elements were arranged at an angle to form a serrated and efficient cutting edge. The flints have characteristic diagonal "scars", as a result of prolonged use (Гюрова 2008, 42). Judging by the preserved chipped stone items in the grooves, three of the Samovodene sickles certainly resemble the Karanovo type (№ 015; 071; 072). At the edges of the groove of the same sickles, polished dents had been formed, at a relatively equidistant spacing from each other (№ 039; 071), most likely due to the counteraction of the plant sheafs during harvesting, in the zone where the chipped stone items overlap. This variation may include the sickles of Provadia-Solnitsata, related to the period of Karanovo III-IV (Николов 2009, 17-20). Two sickles with straight and perforated proximal ends are particularly interesting (Николов 2009, 18, обр. 3, 19, обр. 4). Such proximal shaping is not known in the Karanovo type and is probably a result of other cultural influences.

\section{Punching tools}

Nineteen punching tools were found at the Neolithic tell Samovodene (Fig. 5: B). All of them were made from tine tops, which were removed from the antlers by sawing. These tools hadn't been finely processed: traces of smoothing or scraping are missing.

A number of experimental studies have shown that their use is related to the lithic industry: they were used to strike stones in order to transform them into retouched tools. Use-wear traces may include deep grooves and incisions, generally perpendicular or slightly diagonal to the main axis of the objects, but large damage may also occur on antler surface (Vitezović 2013, 31-32; Гуадели 2011, 37). Traces of such actions can indeed be observed on the surface of the material from Samovodene (Fig 6: 050). They are to be found on different parts of the objects: at the top, longitudinally or on the back. Different types of traces can also be distinguished. Short parallel incisions are usually located on the distal part, which are obtained as a result of the retouching of chipped stone tools. Dents, also located on the distal part, were obtained as a result of compression. 


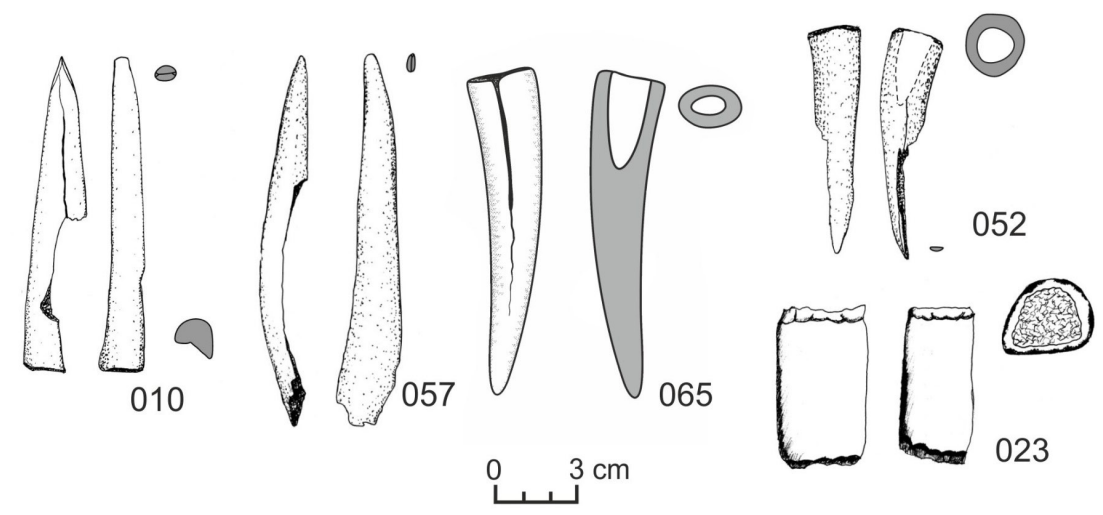

A

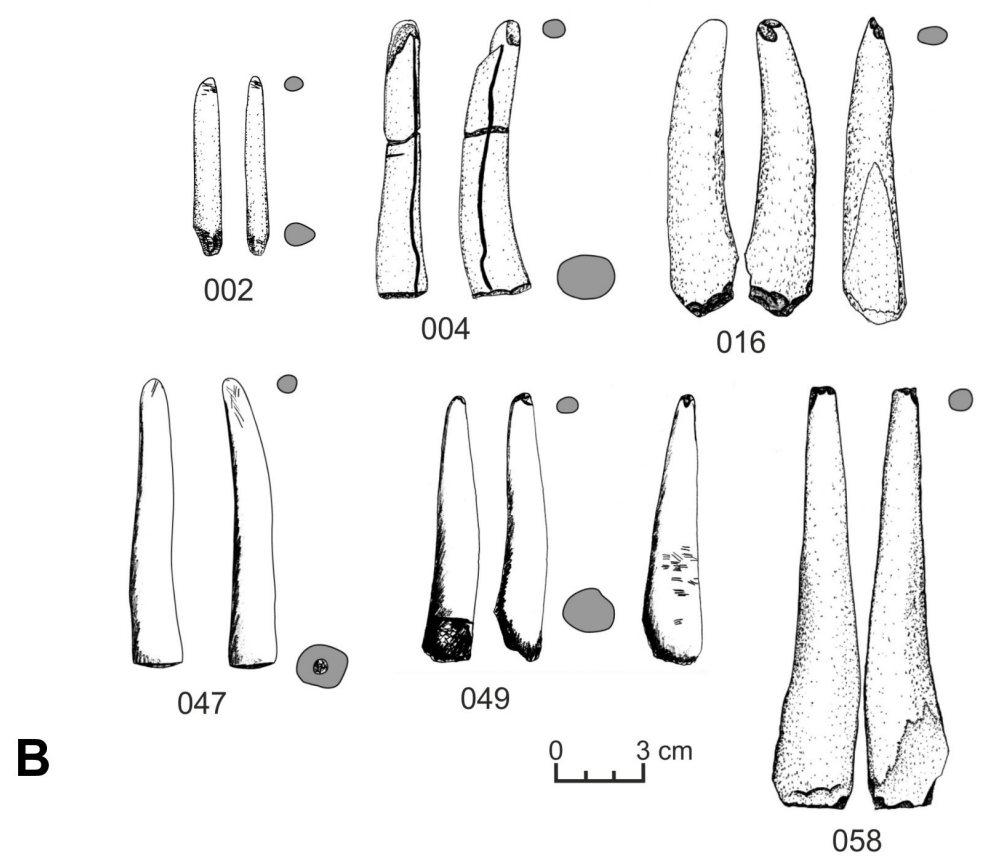

Fig. 5. A. Bevelled tools and sockets; B. punching tools

Сл. 5. А. Алатке са сечицом и усадници; Б. Алатке за ударање 

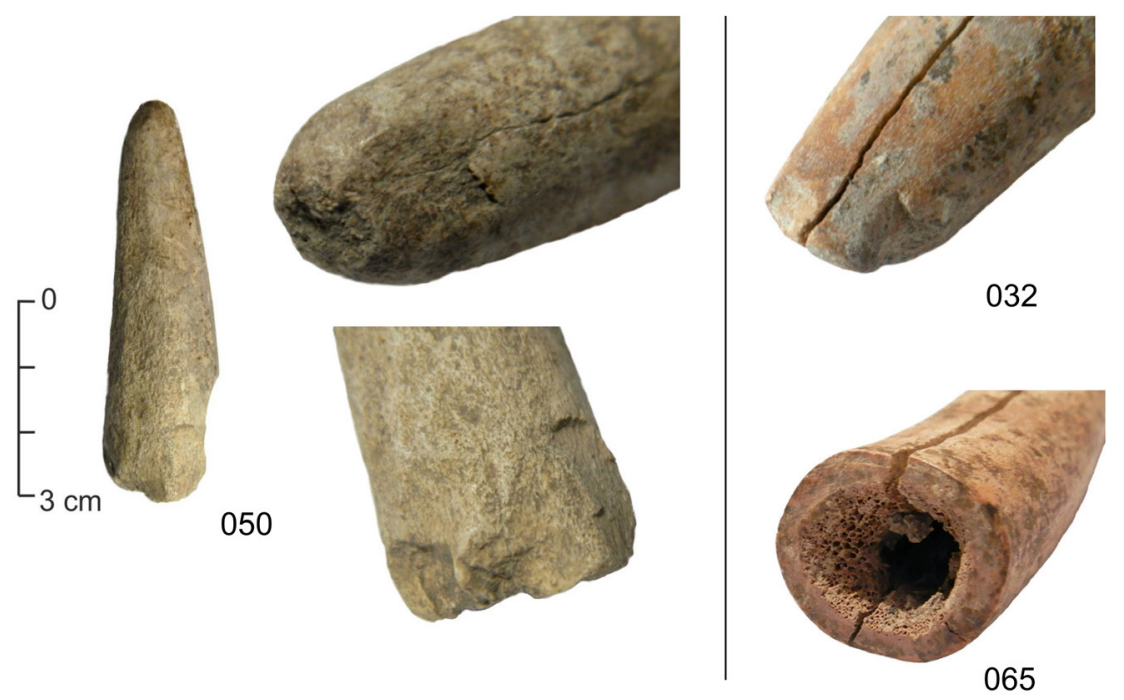

Fig. 6. Details of a punching tool, bevelled tool and socket

Сл. 6. Детаљ алатке за ударање, алатке са сечицом и усадника

The ends of some tools have flaking and crushing because of rough presses and strikes. These items have probably been used to remove flakes from lithic cores.

This kind of tools made of long bones are known on the territory of Bulgaria from the Middle Palaeolithic in the cave of Kozarnika near the town of Belogradchik and continue their development in the Late Palaeolithic period (Guadelli et al. 2013, 155, 157). This type of tools hasn't been registered in layers from the very beginning of the Neolithic in archaeological publications as yet. The appearance of punching tools made of red deer antlers is connected with the third phase of the Early Neolithic, and they were identified in the Ovcharovo-Samovodene culture (third and fourth phase of the Early Neolithic) (Маркова 2018, 136).

\section{Bevelled tools}

Three antler objects have bevelled edges (Fig. 5 A: 010; 057). They were produced by transversal chopping with stone edged tool. They have an elongated shape and a slender form. The active tip was formed by abrasion: one-sided (№ 32 ) and two-sided (№ 10, 57). It is not possible to determine the function of these objects with certainty. Judging by the traces on the surface of the distal end (flaking and scratching) (Fig. 6: 032), it can be assumed that they were used as chisels or wedges in woodwork or for splitting long bones. The appearance of bevelled tools made of antler is also linked to the Ovcharovo-Samovodene culture from that period (Маркова 2018, 136). 


\section{Sockets}

There are three antler objects defined as sockets (Fig. 5 A: 023; 052; $065)$. These are relatively short antler pieces with carved spongy tissue for attaching a bone or a chipped stone tool (Fig. 6: 065). All of them were made of red deer antler tine tips and only one was made of the proximal part of the tine (Fig. 5: 023). Two methods for separating blanks are identified: by chopping with a stone tool (Fig. 5: 023) and by sawing with a chipped stone tool (Fig. 5: 052, 065). Traces of these actions are visible at the edges of the objects. The spongy tissue is carved out over $4 \mathrm{~cm}$ in depth and this was probably performed with a chipped stone or even a bone tool, having in mind the low hardness of the spongy tissue itself (Fig. 6: 065).

\section{Undetermined objects}

There is an object with a finished form and traces of processing that cannot be placed into any classification group. This is an antler tool segment that belongs to the phase Samovodene B1. The entire surface is black and polished as a result of burning. Perhaps it is a small hammer with a perforation for attaching a handle. There is a small two-sided drilled perforation at the medial part and the proximal part has traces of blows (fractures and flaking). Perforated hammershaped objects are known from the Neolithic settlement "Golo Bardo" near the village of Gradishte (Pleven district). Several massive and smaller hammers were found there, rather similar to those of Samovodene (Маркова 2020, 29).

\section{Debris}

There are 23 unidentified antler objects with traces of processing (cutting, chopping, smoothing, scraping or string rubbing). All of them are tines and there is no burr or beams. There are several small tine tips that were probably waste from the production of sickles or sockets (№ 3, 13, 36, 38). Others may have been stored or intended for blanks (№ 7, 12, 42, 43, 73, 75).

\section{Conclusions}

The Neolithic inhabitants of Samovodene must have been obtaining red deer antlers from the surrounding area, if we take into account the rich fauna and large number of red deer bones from the settlement layers. That means that hunting or gathering was a planned, seasonal activity and could be associated with other activities of gathering or exploring. Other Neolithic sites also have a relatively rich collection of worked antlers, such as Katchica, Dzhulyunitsa-Smardesh (Маркова 
2018) and Gradishte (Маркова 2020), indicating that a sufficient number of red deer populations were inhabiting the area during that period. Furthermore, a comparison of the collections from the Early Neolithic and also the existence of fairly identical elements in the antler industry between the settlements prove that there was a uniform standard in the production of these objects, and also that same needs were to be met in the life of populations during the Neolithic.

The population of Samovodene seems to have preferred the tips of the tines for the production of antler objects, which is not surprising as the use of the naturally sharpened tips is perfectly suited for making sickles or punching tools. Even in the case of bevelled tools the tips were not cut, but rather transformed by one-sided or double-sided sharpening. Usually, these objects made of tine tips have a naturally smoothed surface because the antlers would get tangled in the trees, be used for digging the ground or for fighting with other deer. Few items were made from the proximal sections of branches and trunk segments, such as some sockets, for which a portion of the contact area between the stem and some of the tines had been separated. There is no evidence of the beam and the burr having been used for making tools, even among the debris.

Red deer antlers were definitely a very important raw material at the Neolithic site of Samovodene and no other processed antlers were found at the site from other Cervidae species. The antler exploitation was not accidental, since antler parts used were being selected according to the object that was to be made. They were always used for objects intended for rougher activities (striking, digging, loosening the soil, for agricultural activities, etc.), which can be brought into connection with the mechanical properties of the raw material (hardness, elasticity), which were well-known to the Neolithic men. Antlers were used mainly to produce every-day items, along with stone, flint and bone. There is no evidence in the assemblage that antlers were used for hunting weapons or special items. The production was very specialized because the objects from that collection were processed in a standardized manner and the toolkit concentrated around two main types of tools related to agriculture and chipped stone industry.

The antler objects of tell Samovodene are typologically and quantitatively equally distributed over the chronological phases of the settlement, with the exception of the later phase Samovodene B2-C, which has been barely excavated. It seems that the Neolithic population had a very strong tradition of manufacturing objects from red deer antlers, which is another proof of a peaceful continuity of life in this place. This also indicates a continuity in their economic life: the objects occur over a long period of time of 300-400 years (5970-5747 cal BC to 5484-5375 cal BC) (Marinova, Krau $\beta$ 2014, Table 2, p. 190). The only tendency 
that can be noted is the absence of sockets during the early phases of Samovodene A and Samovodene A2-B1 and their gradual appearance from Samovodene B1. This was undoubtedly caused by changes in the system of holding the tools: most likely with the development of one craft or the improvement of another. The rather well-standardized technology and the simple set of tools indicate a good knowledge of antler properties and qualities that enabled them to adapt them very well to the needs of the Neolithic way of life.

The antler tools of Samovodene have similarities with collections from Central Northern and North-eastern Bulgaria, such as Dzhulyunitsa-Smardesh IV (Маркова 2018), Ovcharovo-Gorata (Zidarov 2014) and Gradishte-Golo Bardo (Маркова 2020). They present the same types of sickles and sockets, except for punching tools and bevelled tools, which seem to be missing at Ovcharovo, as seen from the published materials (Zidarov 2014). The Neolithic collection from Golo Bardo is quite similar and red deer antler exploitation is also very well represented, and, in addition to sickles and retouchers, there are several chisels (Маркова 2020,28). It is not a coincidence the both antler industries are identical because the settlements were located in the same micro area and it can be presumed that there were cultural contacts between them. In addition, both settlements are located on high non-flooding terraces (Попов et al. in press; Станев 2002, 12), which implies a similar ancient ecological environment.

Analogies for antler tools from Samovodene can be found on Neolithic sites located in other regions, such as tell Karanovo (Höglinger 1997, 193), Starčevo, Velesnica, Donja Branevinja (Vitezović 2014), etc. The collection from the southern sector of tell Karanovo (Southern Bulgaria) is poorly presented in terms of antler objects: three sickles and 13 "Geweihspitzen" dated into the Karanovo I and Karanovo II cultures (Höglinger 1997, 193-194). Are the antler objects really typical only for the two earliest layers in Karanovo and why are they missing at Karanovo III? If so, the presence of antler sickles and perhaps "Geweihspitzen", which continued in later stages at Samovodene, can be taken as another proof of local traditional continuities in red deer antler processing.

\section{Discussion}

The production of red deer antler tools was very specialized in terms of technology and typology because the Samovodene collection is very well standardized and the toolkit focused on two main types/instruments related to agriculture and flint knapping. The Neolithic inhabitants of Samovodene knew this kind of raw material very well since the beginning of life in the settlement, which proves that the knowledge of antler industry had been learned elsewhere and had 
been passed on to Samovodene through generations. The hypothesis presented in earlier archaeological studies claimed a probable reneolithisation of Central Northern Bulgaria by a population which came from Thrace to the north of the Stara Planina Mountain and created the settlement in Samovodene (Тодорова, Вайсов 1993, 132). On the other hand, there are four prehistoric settlements in the region of Central Northern Bulgaria that have been excavated as well: Belyakokvets-Plochite, Dzhulyunitsa-Smardesh, Koprivets and Orlovets. There, layers from the two earliest phases of the Early Neolithic have been discovered: the phase with monochrome pottery and the phase of white-painted pottery (Вайсов, Попов 2014, 50; Еленски 2004, 67; Еленски 2006, 96-117; Еленски 2008, 773; Станев, Еленски 1998, 311). The earliest inhabitants may have migrated in different directions in the area in order to find better places for living when the resources were spent, or perhaps smaller groups of people opted to separate. When it comes to antler collections from the above-mentioned Neolithic settlements, they are too small or sometimes completely missing (Belyakovets-Plochite), and thus we cannot bring them into connection with Samovodene antler tools. Future excavations and detailed studies of every aspect of Neolithic way of life in the Middle Yantra River would clarify the movement of people and ideas.

Acknowledgements: The results of the study of worked red deer antlers from Samovodene were presented at a session of the Annual Meeting of the Serbian Archaeological Society, held in Negotin, from May $30^{\text {th }}$ to June $1^{\text {st }} 2019$, to which I was invited by Dr. Selena Vitezović, for which I thank her very much. Furthermore, the studying of the material is a part of my master thesis, defended at Veliko Tarnovo University in Bulgaria, for which Dr. Vitezović was my supervisor.

\section{REFERENCES}

Beldiman, C, Sztancs, D.-M. 2010. Technology of skeletal materials of the StarčevoCriş Culture in Romania. Some considerations, in The First Neolithic Sites in Central/ South-East European Transect. Volume II, Early Neolithic (Starčevo-Criş) Sites on the territory of Romania, eds. S. Adrian Luca, and C. Suciu, 57-70. Oxford: Archaeopress, BAR International Series 2188.

Billamboz, A. 1977. L'industrie du bois de cerf en Franche-Comté au Néolithique et au début de l'Age du Bronze. Gallia préhistoire 20/1: 91-176.

Crigel, M.-H., Balligand, M., Heinen, E. 2001. Les bois de cerf: revue de literature scientifique. Annales de médecine veterinaire 145 (1): 25-38.

Еленски, Н. 2001. Археологически проучвания в селищната могила в с. Самоводене, Великотьрновско, през 2000 г, in Археологически открития и разкопки през 1999-2000 2., 2001, eds. Redaktor?, 18-20. НАИМ-БАН: София. 
Еленски, Н. 2004. Културни контакти през ранния неолит на централна Северна България с Тракия и района на Мраморно море, in Праисторическа Тракия. Доклади от международния симпозиум в Стара Загора 30. 09 - 04. 10. 2003, eds. В. Николов, К. Бъчваров, П. Калчев, 67-79. НАИМ-БАН: София -Стара Загора.

Еленски, Н. 2006. Сондажни проучвания на раннонеолитното селище Джулюница-Смърдеш, Великотьрновско (предварително съобщение). Археология XLVII/1-4: 96-117.

Еленски, Н. 2008. Раннонеолитното селище Беляковец-Плочите, Великотьрновско. Известия на Регионален исторически музей-Велико Търново XXIII: 7-73.

Георгиев, Г. Ил. 1958. За някои оръдия за производство от неолита и енеолита в България, in Изследвания в чест на акад. Димитьр Дечев, eds. (В. Бешевлиев, Вл. Георгиев), 369-387. Издание на Българската академия на науките: София.

Георгиев, Г. Ил. 1960. Главни периоди в развитието на неолита и медната епоха в България в светлината на най-новите проучвания. Swiatowit 23: 309-339.

Гуадели, А. 2011. Костни артефакти от палеолита в България. Дисертации, том 6. Национален археологически институт и музей - Българска академия на науките: София.

Guadelli, A., Fernandez, Ph., Guadelli, J.-L., Miteva, V., Sirakov. N. 2013. The Retouchers from the Gravettian Levels in Kozarnika Cave, in The Sound of Bones. Proceedings of the 8th Meeting of the ICAZ Worked Bone Research Group in Salzburg 2011, ed. F. Lang, 155-162. Salzburg: Archæoplus, Schriften zur Archäologie und Archäometrie an der Paris Lodron-Universität Salzburg.

Гюрова, М. 2008. Праисторическите земеделски сечива - индикатори на неолитизационния процес, In Праисторически проучвания в България: Новите предизвикателства. Доклади от националната конференция по праистория, Пещера 2629.04.200, ed. М. Гюрова), 39-55. Национален археологически институт и музей - Българска академия на науките: София.

Gurova, M. 2016. Prehistoric sickles in the collection of the National museum of archaeology in Sofia, in Southeast Europe and Anatolia in prehistory. Essays in honor of Vassil Nikolov on his $65^{\text {th }}$ anniversary, eds. K. Bacvarov, and R. Gleser. 159-165. Universitätsforschungen zur prähistorischen Archäologie Band 293 Aus der Abteilung für Urund Frühgeschichtliche Archäologie der Universität MünsterVerlag Dr. Rudolf Habelt $\mathrm{GmbH}$ : Bonn.

Höglinger, P. 1997. Neolithisches Bein- und Geweihgerät, in Karanovo. Die Ausgrabungen im Südsektor 1984-1992, eds. S. Hiller, and V. Nikolov, 157-196. Band I. 1. Salzburg-Sofia: Archäologisches Institut der Universität Salzburg-Archäologisches Institut mit Museum der Bulgarischen Akademie der Wissenschaften, Sofia.

Ланг, Ф. 2004. Хронологично представителни типове костни оръдия от тел Караново. in Праисторическа Тракия. Доклади от международния симпозиум в Стара Загора 30.09-04.10.2003, eds. В. Николов, К. Бъчваров, П. Калчев, 359-369. Национален археологически институт и музей - Българска академия на науките: София: София-Стара Загора. 
Marinova, E. and Krauß, R. 2014. Archaeobotanical evidence on the Neolithisation of Northeast Bulgaria in the Balkan-Anatolian context: chronological framework, plant economy and land use. Bulgarian e-Journal of Archaeology 4: 179-194.

Маркова, Хр. 2018. Костената индустрия от неолита по средното течение на река Янтра. Магистистьрска теза). Велико Търново: Великотърновски университет “Св. Св. Кирил и Методий”.

Маркова, Хр. 2020. Предмети от твърда животинска материя от неолитното селище „Голо бърдо“ до село Градище (предварително съобщение). іn Мизия от древността до днес, том II, ред. В. Попов, Пл. Лаков, А. Михова, А. Караиванова, М. Йорданова, С. Григорова, 24-36. Faber: Велико Търново.

Mellaart, J. 1970. Excavations at Hacılar. Edinburgh: University Press.

Николов, В. 1998. Проучвания върху неолитната керамика в Тракия. Керамичните комплекси Караново II-III, III и III-IV в контекста на Северозападна Анатолия и Югоизточна Европа. София: Агато́.

Николов, В. 2009. Колективна находка от къснонеолитни сърпове в тел ПровадияСолницата, in Сборник в памет на професор Велизар Велков, eds. Хр. Попов, and A. Тенчова, 15-22. Национален археологически институт и музей - Българска академия на науките: София.

Нинов, Л. и Станев, П. 1992. Животновъдна и ловностопанска дейност на населението от неолитната селищна могила Самоводене - археозоологични анализи. Известия на Исторически музей Велико Търново VII: 117-126.

Петков, Р. 1999. Дивечът. Мари 90: София.

Попов, В., Вайсов, И., Евлогиев, Й., Маркова, Хр., Марков, Др., Джурковска, Г. In press. Нео-енеолитно селище ,Голо бърдо“.

Russell, N. 2016. Anatolian Neolithic Bone Tools. Anatolian Metal VII. Der Anschnitt. Zeitschrift fur Kunst und Kultur im Bergbau 31: 125-134.

Семёнов, С. А. 1957. Первобытная техника (опыт изучения древнейшех орудий по следам работы). Материаль и исследования по археологии СССР 54: 9-31.

Schibler. J. 2013. Bone and antler artefacts in Wetland sites, in The Oxford handbook of Wetland archaeology, eds. F. Menotti, and A. O'Sullivan, 339-355. Oxford: Oxford University Press.

Sidera, I. 1998. Nouveaux éléments d'origine Proche-Orientale dans le Néolithique ancien balkanique: analyse de l'industrie osseuse, in Préhistoire d'Anatolie. Genèse de deux mondes, ed. M. Otte, 215-239. ERAUL: Liège.

Станев, П. 1982. Стратиграфия и периодизация на неолитните обекти и култури по басейна на река Янтра. Годишник на музеите от Северна България VIII: 1-15.

Станев, П. 1997. Неолитна селищна могила Самоводене - резултати от досегашните проучвания. Известия на Историческия музей - Велико Търново XII: 38-61.

Станев, П. 2002. Самоводене. Неолитна селищзна могила. Фабер: Велико Търново.

Станев, П. и Еленски, Н. 1998. Раннонеолитно терасно селище “Плочите” Велико Търново. Дни на науката: 3-11. 
Тодорова, Х и Вайсов, И. 1993. Новокаменната епоха в България. Наука и изкуство: София.

Вайсов, И. и Попов, В. 2014. Неолитно селище Копривец (археологически проучвания), in Археологически открития и разкопки през 2013 г., ed. М. Гюрова, 49-54. НАИМ-БАН: София.

Vitezović, S. 2013. Retouching Tools from Osseous Raw Materials in the Starčevo Culture. - Haemus Journal 2: 31-42.

Vitezović, S. 2014. Antler as raw materials in the Starčevo culture, in Archaeotechnology. Studying technology from prehistory to the Middle Ages, eds. S. Vitezović, and D. Antonović, 151-176. Serbian Archaeological Society: Belgrade.

Vitezović, S. 2016. Metodologija proučavanja praistorijskih koštanih industrija. Srpsko arheološko društvo: Beograd.

Vitezović, S. 2017. Antler exploitation and management in the Vinča culture: An overview of evidence from Serbia. Quaternary International 450: 209-223.

Vitezović, S. 2018. Fishing and hunting gear from osseous raw materials in the Early Neolithic from Serbia. Quaternary International 472: 38-48.

Zidarov, P. 2014. Knochen- und Geweihgeräte: Traditionen und Praktiken im Alltag der Einwohner von Ovčarovo-Gorata, in R. Krauß, Ovčarovo-Gorata. Eine frühneolithische Siedlung in Nordostbulgarien, 250-270. Habelt Verlag: Bonn. 


\title{
Христина Маркова
}

Историјски музеј Нова Загора, Бугарска

\section{РОГОВИ ЈЕЛЕНА КАО СИРОВИНА НА НЕОЛИТСКОМ ЛОКАЛИТЕТУ САМОВОДЕНЕ, ОБЛАСТ ВЕЛИКО ТРНОВО (ЦЕНТРАЛНА СЕВЕРНА БУГАРСКА)}

\author{
Кључне речи: оруђе од рога јелена, технологија рога, типологија \\ предтема од рога, рани неолит; ичентрална северна Бугарска
}

Неолитски локалитет Самоводене (област Велико Трново) смештен је у североисточном делу савременог села Самоводене, на узвишеној заравни која није била плављена, на левој обали реке Јантре. Археолошка истраживања обављена су у неколико кампања: 1974. године заштитна ископавања спровео је Петар Станев, а у периоду 1999-2000. године Недко Еленски. Издвојено је укупно пет културних слојева и једанаест стамбених хоризоната, без видљивог хијатуса, што Самоводене чини једним од најзначајнијих неолитских локалитета у доњем току Дунава.

Археозоолошка анализа показала је да је удео јелена (Cervus elaphus) био висок у фауналним остацима, одмах иза говечета (Bos taurus). На локалитету је откривена и богата коштана индустрија од око 350 артефаката, од чега је око 80 било начињено од рога јелена. Предмети од рогова могу се класификовати у шест група: српови, алатке за ударање, алатке са сечицом, дршке и неодредиви предмети. Равномерно су налажени у свим слојевима, осим у слоју В2-С, где су откривена само два артефакта.

Пронађено је укупно 18 српова, који су доста фрагментовани. Морфолошки, издвајају се две варијанте: закривљени и српови у облику латиничног слова L. Израђивани су тако што се алатком од окресаног камена начини жлеб са унутрашње стране кривине рога, у који су постављане окресане камене алатке. Често су финално обрађени глачањем и полирањем. Српови се, иначе, сматрају делом „неолитског пакета” и познати су и са других балканских и анадолских неолитских локалитета (Караново, Овчарово-Гората, и други).

Укупно деветнаест алатки припадају групи алата за ударање. Све су израђене од парожака круне, одвојени тестерисањем од преосталог дела. Ове алатке биле су мање фине израде; трагови финог глачања на њима нису нађени. Ови су предмети највероватније служили као ретушери.

Три алатке припадају алаткама са сечицом. Произведене су трансверзалним сечењем сегмената рога. Имају издужену, танку форму, а радни 
крај формиран је помоћу једностране или двостране абразије. На основу трагова употребе који су на њима уочени, можемо претпоставити да су коришћене као нека врста клина или длета у обради дрвета или за расцепљивање дугих костију.

Међу усаднике сврстана су три предмета, израђена од сразмерно кратких сегмената рога, са спонгиозним ткивом које је издубљено.

Откривен је и један предмет чији се тип није могао одредити, нагорео, могуће мањи чекић са перфорацијом за дршку.

Осим готових предмета, откривена су и двадесет три фрагмента рога јелена са траговима обраде (сечење, цепање, глачање, стругање, итд.). Ради се искључиво о парошцима, док фрагменти базног дела или стабла нису нађени.

Производња алатки од рога јелена била је веома посебна како по питању технологије, тако и типологије, и можемо уочити да је ова сировина била коришћена понајвише за два основна типа алата који су повезани са обрадом земље и са литичком индустријом. Сразмерно добро стандардизована технологија и једноставни сетови алата указују на добро познавање својстава и одлика рога јелена и њихову адаптацију на неолитски начин живота. Чини се да су становници Самоводена познавали ову сировину доста добро од самог почетка живота у овом насељу, што показује да је знање о индустрији рога било усвојено негде другде и да је на Самоводену преношено из генерације у генерацију. 